\title{
ACCOUNTANT EN ACTUARIS: THEORIE EN PRAKTIJK
}

\section{door H. L. F. Verbraak, actuaris}

In het MAB van juli/augustus $1975 \mathrm{kwam}$ een artikel voor van de hand van de heer J. C. Haak, getiteld „De accountantscontrole van een levensverzekeringsmaatschappij en de verklaring bij de jaarrekening ervan".

Dat artikel is interessant, vanzelfsprekend ook voor actuarissen. Haak betoogt, dat de accountant in zijn verklaring niet behoeft te verwijzen naar de actuaris. Als dat zo is, dan is tevens het lastige vraagstuk opgelost, hoe een accountant vertrouwen zou moeten wekken op basis van een verwijzing naar het werk van een interne functionaris (die eventueel de verzekeringsdirecteur zelf kan zijn). Ik kan mij echter niet geheel verenigen met het betoog van Haak. Het kan natuurlijk zijn, dat zijn redenering past in formele denkprocédé's, die decennialang rond de goedkeurende verklaring zijn gegroeid in de accountantswereld. En dan is zijn redenering wellicht formeel juist. Maar materieel liggen de zaken niet zo eenvoudig.

Haak's suggestie, dat de verwijzing naar de actuaris niet zinvol zou zijn, steunt blijkbaar op zijn volgende globale betoog:

a. de actuaris is in hoofdzaak een wiskundige en weet niet veel van bedrijfseconomische grondslagen resp. van controleleer;

$b$. de accountant weet van bedrijfseconomische grondslagen en van controleleer; zijn manco is aldus maar klein en hij kan steunen op objectieve inzichten uit hoofde van de analyse van de jaarrekening;

c. het kleine manco van de accountant behoeft hem niet te weerhouden van een goedkeurende verklaring zonder verwijzing naar de actuaris met $z$ 'n forse manco.

Wat is nu de werkelijkheid? Men kan die strikt materieel zien en bedenken, dat noch accountants noch actuarissen allrounders binnen hun vak zijn, dat ze niet allemaal vandaag zijn klaargekomen met hun opleiding en dus ook niet allemaal op de hoogte zijn van wat heden ten dage geldt als vaktechnisch correct, dat ze ook verder in hun werkkring niet altijd 100\%-technisch hun standpunt kunnen uitdragen en dat ze dus al blij mogen zijn een redelijk verstandige gesprekspartner te vinden.

Voor zover de verklarende accountant zich daardoor in feite zekerder kan voelen dan zonder actuaris, kan alleen een formele redeneerwijze hem nog belemmeringen in de weg leggen om naar de actuaris te verwijzen (gesteld even - ter vermijding van andere bezwaren - dat die actuaris een externe actuaris is). Maar zo strikt materieel mag natuurlijk nooit gedacht worden, want zonder formaliseren is het nu eenmaal moeilijk om ordelijkheid te betrachten. Hoe liggen dan de onderlinge verhoudingen meer formeel?

Welnu: de actuaris is niet in hofdzaak een wiskundige. Mede tegen de achtergrond van opleidingsnormen is een actuaris wel iemand, die geschoold is in kwantitatief denken en daartoe is hem ook als hulpmiddel een zekere 
portie wiskunde bijgebracht. Hij kan dat hulpmiddel toepassen op statistische problemen en economische vraagstukken. In zijn opleiding leert hij dan ook zaken over financieringsleer, economie, analyse van jaarresultaten, statistiek en recht. Misschien is zijn opleiding voor minder dan de helft gericht op de ontwikkeling van zijn wiskundig apparaat en voor het overige op de praktische toepassing.

Tekenend is wel, dat aan de UVA de actuariële opleiding wordt verzorgd door de "Interfakulteit voor Actuariaat en Econometrie"; actuarissen en econometristen hebben voor een groot deel dezelfde opleiding.

Als actuarissen nu werkelijk zo weinig wisten van andere dingen dan van wiskunde, zouden ze dan in staat zijn als technisch brein te fungeren bij vrij complexe ondernemingen, die automatiseren, jaarrekeningen en resultatenanalyses opstellen en dan nog redelijk blijken te floreren ook?

$\mathrm{Nu}$ kan men natuurlijk stellen, dat iemand die bijv. schroot koopt en verkoopt en wel zonder tijdsverloop, wel een goede zaak kan hebben zonder nochtans enig begrip te hebben van de heersende bedrijfseconomische jaarrekeningsadat.

(N.B. Ook de ,exacte” empirische wetenschappen pretenderen niet, de „waarheid" te kennen, maar beogen slechts iets zodanigs te benaderen en wel hopelijk steeds beter; , adat" verdraagt zich dan ook zelfs met de fysika en is geenszins denigrerend bedoeld). Maar het hele proces van verzekeren op langere termijn eist bij voorbaat een zekere bedrijfseconomische kennis, die verder gaat dan bij een voor het gemak maar irreëel primitief gedachte onderneming.

Dat volgens Haak actuariële kennis op zich geen deugdelijke grondslag kan zijn voor een verklaring die vertrouwen moet wekken, doet m.i. slechts de vraag rijzen, wat Haak verstaat onder actuariële kennis. En dat Haak zelfs beweert, dat de actuariële verklaring bij de jaarrekening verdacht is bij gebrek aan bedrijfseconomische kennis, doet tevens de vraag rijzen wat Haak onder bedrijfseconomische kennis verstaat.

Is verder het manco van de accountant hier maar klein? Haak antwoordt hierop bevestigend, want - zo stelt hij - het enige wat de accountant mist is inzicht in het manipuleren met sterfteverwachtingen (die toch al vast liggen in officiële tabellen) en inzicht in de berekening zelf (die blijkbaar op het niveau ligt van exercitie aan het prille begin van zijn opleiding en steunt op eenvoudige formules). Dit laatste inzicht kan - volgens hem - trouwens toch redelijkerwijze ontbreken doordat hij de exactheid formeel kan toetsen aan het sluiten van de technische resultatenanalyse.

Welnu, ik kan natuurlijk heel moeilijk beoordelen, of dit accountantsmanco van betekenis is, want als iemand een vak kent, heeft hij geen objectieve voorstelling meer van wat delen van zijn kennis uit studie + ervaring bijdragen tot zijn inzichten. Een zekere behoedzaamheid lijkt mij wel gewenst, want ook al zijn formules uit de kwantum-mechanica eenvoudiger dan die van actuarissen, toch begrijp ik niets van kwantum-mechanica (formules zijn kortschriften uit een denkwereld, meer niet). 
Overigens acht ik het heel wel mogelijk, dat een „normale” accountant, die twee jaar aanvullende actuariële zaken bestudeert (basis-formule-apparaat plus zelfstandig opstellen van resultatenanalyses globaal op die basis) en die verder veel met levensverzekeringsinstellingen te maken heeft gehad en ook heeft, inderdaad geheel op eigen wieken tot een verklaring kan komen. Dit laatste mits hij zich kritisch door een actuaris laat voorlichten over de redenen, waarom de verschillende kanssystemen tot verliezen en winsten voeren (door toeval en/of door marges en misschattingen).

Maar omgekeerd moet het toch ook voor een actuaris mogelijk zijn om in twee jaar door verdieping in bedrijfseconomische zaken, in speciaal gerichte controleleer (de statistische methode daarbij zal hem nauwelijks afschrikken) en in de praktijk van de accountantscontrole, op een niveau te komen, dat het hem materieel mogelijk maakt om op eigen wieken verklaringen over de jaarrekening van verzekeringsinstellingen af te geven. Bij dit alles neem ik dan aan, dat zowel de betrokken accountant als actuaris voldoende extern zijn. Toch heeft geen actuaris in zijn spiegelbeeldverhouding van incompleetheid, ooit de pretentie er zonder accountantscontrole uit te komen.

Zelf heb ik al jaren met vele accountants in een redelijke symbiose samengewerkt, om tot een goede controle op jaarrekeningen te komen; dat lukt heel wel; ik heb de indruk dat de accountants mij als specifiek expert alle ruimte geven ook bij het helpen construeren van jaarrekeningen.

Inderdaad is dan de technische resultatenanalyse een middel tot het verkrijgen van inzicht in de juistheid van het resultaat, een soort afrondende, all round controleregel; maar die is van formele aard. Er volgt op zijn hoogst uit, dat alle mutaties in het verzekeringsbestand zijn verricht conform de geldende systematiek en in overeenstemming met de mutaties in premiën en uitkeringen. Maar niet bijv. of in de balans een juist ,vermogen" tot uitdrukking komt. Enkele accountants verwijzen dan tegenwoordig niet, de meesten wel. Dat is, op het niveau van praktisch werken, geen echt probleem, want de actuaris vraagt niet om een verwijzing. Maar iets anders wordt het volgens mij, als aan het niet-verwijzen theoretische principes ten grondslag liggen, die geheel los staan van de werkelijkheid.

Gezien het voorgaande ben ik van mening, dat de accountant er, althans in zijn eigen opvattingen, niet onderuit kan naar de actuaris te verwijzen. Aanvullend probleem is dan voor de accountant, dat hij - meestal bij levensverzekeringsmaatschappijen en soms bij andere verzekeringsinstituten - over het algemeen te maken heeft met een interne actuaris. Hij kan dat natuurlijk oplossen, door de aanwezigheid van een externe actuaris te eisen. Maar hij weet, dat dit met name bij levensverzekeraars weer andere, praktischer moeilijkheden geeft, gelegen in het feit, dat externe actuarissen ook werkzaam zijn in eigenbeheerde pensioenfondsen, die door verzekeraars als concurrentie worden ervaren. Maar hij kan dit vraagstuk niet oplossen door toepassing van een beginsel, als zou hij zonder hulp van buiten zijn vakgebied voldoende inzicht kunnen verkrijgen in de aanvaardbaarheid van de cijfers.

Wat ik overigens in Haak waardeer is zijn streven om gegroeide taalconstructies als bijv. „eigen oordeel”, die een vage begripsaanduiding krijgen boven de 
gebruikte woorden uit, op hun plaats te krijgen. Inderdaad zou het interessant zijn om eens een logikus te zetten aan de analyse van de in gedrags- en beroepsregels van allerlei groeperingen gehanteerde begrippen. Maar ik vraag mij af, of Haak zelf niet verknoopt raakt in terminologieën, indien hij zich afvraagt of - gezien de door hem aanwezig geachte ,superioriteit" van de Verzekeringskamer boven de Ondernemingskamer - een "getrouw beeld" in strijd zou zijn met de vereiste solvabiliteit ten opzichte van polishouders. Want wat is een ,getrouw beeld" van resultaat en van vermogen bij huishoudingen die op zo lange termijn moeten waarderen, dat zeer kleine variaties in de keuze van rente, kanssystemen en kostenpeil leiden tot het al of niet aanwezig doen blijken van ,vermogen"?

Ligt de basis van het getrouwe beeld in dergelijke onzekerheidssituaties juist niet in de specifieke wetgeving naast de algemene bepalingen van de WJO? Volgens de WJO zelve zeer zeker, want die geeft juist aan de specifieke gewoonte ruim baan naast de algemene. Dat is geen kwestie van superioriteit, maar van doelmatigheid. Is er in feite echter strijd tussen bedrijfseconomische opvattingen en jaarrekeningen van verzekeringsinstellingen? Uit de verslagen van de Verzekeringskamer blijkt wel, dat men zich ook daar van tijd tot tijd moeite getroost om de formele jaarrekening-technieken te toetsen tegen bedrijfseconomische desiderata, o.m. wegens de voortgaande inflatie.

De kwestie waar het Haak om behoort te gaan is toch, dat er in feite iets fout gaat; het is niet een kwestie van competenties. Denkbaar is trouwens, dat de jaarrekening als publiek stuk zoveel met polishouders heeft te maken, dat deze moet uitgaan van specifieke veiligheidsopvattingen. Ik ben geen bedrijfseconoom, maar mijn indruk is dat de weergave van de vorming van resultaat en vermogen toch niet zonder meer de pijler is voor de verslaggeving. Gesteld eens twee ondernemingen A en B met publieke belangen, die in resultaat en vermogen (volgens een of andere norm) gelijk zijn, maar die overigens verschillen in omzet en in variabiliteit van de resultaten dusdanig, dat de faillissementskans van onderneming A binnen twintig jaren 50\% is en van $B$ maar $1 \%$. Het gaat dan toch ook om de soliditeit: heeft die niets te maken met verklaringen omtrent getrouwe verantwoording?

Ik weet ook niet wat de zin is van de suggesties van Haak, dat het Nivra maar, zoals in de USA, regels voor jaarrekeningen van verzekeringsinstellingen moet aangeven. Wat is dan de formele status van dergelijke regels? Passen die wel in een land waar de wetgeving in het algemeen en in het bijzonder die bij verzekeringsinstellingen juist de redelijke interpretatie, afhankelijk van variërende omstandigheden, normatief stelt? Dat de jaarrekening van een levensverzekeraar volgens gezonde bedrijfseconomische opvattingen moet worden vastgesteld, is buiten kijf, maar als daaraan inhoud wordt gegeven via ,de regels", waarom dan ook maar niet voor andere bedrijfshuishoudingen zo gedaan? Immers ook daar zijn bedrijfseconomische opvattingen nodig.

Ik hoop, dat onze opmerkingen over het stuk van Haak, die materieel bedoeld zijn, niet al te zeer strijdig zijn met het formele kader van de GBR. 